\title{
Commercialisation of Traditional Crops: Are Cassava Production and Utilisation Promotion Efforts Bearing Fruit in Kenya?
}

\author{
Milcah W. Mulu-Mutuku ${ }^{1}$, Dolphine A. Odero-Wanga ${ }^{1}$, Adijah M. Ali-Olubandwa ${ }^{1}$, \\ Joyce Maling'a ${ }^{2} \&$ Amos Nyakeyo ${ }^{3}$ \\ ${ }^{1}$ Egerton University, Njoro, Kenya \\ ${ }^{2}$ Kenya Agricultural Research Institute, Njoro, Kenya \\ ${ }^{3}$ National Drought Management Authority, Kenya \\ Correspondence: Milcah W. Mulu-Mutuku, Egerton University, Njoro, Department of Applied Community \\ Development Studies, P.O. Box 536, Egerton 20115, Kenya. Tel: 254-722-367-394. E-mail: \\ mwmilcah@yahoo.com/mmulu@egerton.ac.ke
}

Received: May 4, 2013 Accepted: May 29, 2013 Online Published: June 13, 2013

doi:10.5539/jsd.v6n7p48 URL: http://dx.doi.org/10.5539/jsd.v6n7p48

\begin{abstract}
Achieving food security has been an elusive goal for many economies in Sub-Saharan Africa. Among the strategies being pursued to achieve this goal is agribusiness development through strengthening smallholder farmers' entrepreneurial capacity and promotion of traditional crops production and utilisation. Cassava has been identified as a high value traditional crop that has enormous industrial value. In Kenya, it has been promoted by the government and other interested organisations. However, despite the efforts, cassava has not evolved from subsistence to a commercial crop that can be relied on in the fight against food insecurity. This paper examines the level of adoption of cassava commercialisation technologies by smallholder farmers in Kenya. It is based on a study conducted in Ngata Division of Nakuru District Kenya where 99 smallholder household heads who are members of cassava common interest groups were interviewed and stakeholder discussions held. Data was analysed using descriptive statistics and stakeholder discussions analysed thematically. Though cassava was grown by $57 \%$ of the households, very few $(6.1 \%)$ engaged in entrepreneurial activities involving cassava, selling only the raw tubers. Cassava tended to be grown by older farmers as compared to younger farmers. Smallholder farmers encountered challenges in cassava production, cassava utilisation and cassava commercialisation. For cassava to contribute towards food security, a market-oriented approach that focuses on empowering farmers for entrepreneurial action may need to be considered.
\end{abstract}

Keywords: cassava commercialisation, challenges to cassava commercialisation, entrepreneurial activities, smallholder farmers, Kenya

\section{Introduction}

Kenya has been experiencing declining per capita agricultural production with total annual on-farm production of food crops lagging behind consumption. This has resulted in food deficits and the consequential food insecurity being witnessed in the country (Kenya Agricultural Research Institute [KARI], 2011), especially in arid and semi-arid areas. Achieving household food security has been an elusive goal, not only for Kenya, but in Sub-Saharan Africa where population has continued to increase with agricultural production not matching population growth (Hazell \& Poulton, 2007; Muzari, Gatsi \& Muvhunzi, 2012).

Food security is defined as a situation that exists when all people, at all times, have physical, social and economic access to sufficient, safe and nutritious food that meets their dietary needs and food preferences for an active and healthy life (Food and Agriculture Organisation [FAO], 2002). It encompasses not only food production, but also the ability of individuals to access adequate, affordable and socially acceptable varieties of foods for health living (FAO, 2002). With agriculture being the backbone of many Africa's economies, it is plausible to expect food security to be achieved through innovations in the agriculture sector much more faster than through innovations in any other sector of the economy.

In the past, agricultural innovations in Kenya concentrated on improvement of production of major food crops such as maize, wheat, rice, beans and Irish potato (Government of Kenya [GoK], 2005) and the importation of 
western technologies (Muzari et al., 2012). However, little attention was placed on the improvement of traditional food crops production and on development of entrepreneurship among smallholder rural farm households necessary for commercialisation of agricultural activities (GoK, 2007). Commercialisation of agricultural activities among smallholder households has been touted as a crucial means of achieving food security (GoK, 2005). Other than increasing income for households, it promotes efficient use of scarce resources in rural areas leading to faster development (Dannson, Ezedinma, Wambua, Bashasha, Kirsten \& Satorius, 2004). One major hindrance to achieving food security is low level of value addition especially through agro-processing which can impact on food security by reducing food losses, increasing food availability and improving access to food (GoK, 2004; Thapa, 2000).

In recent times, agriculturists and extension workers in Kenya have incorporated the development of entrepreneurial capabilities among rural farm households and the commercialisation of traditional crops production into their agenda, encouraging farmers to develop entrepreneurial capabilities. Some traditional crops with the capacity for commercialisation have been identified for promotion. These include cassava, one of the high value traditional crops with the ability to withstand adverse climatic conditions and an important food security crop for resource poor households (GoK, 2005).

Due to its importance as food and an industrial raw material especially in livestock feed, starch, alcohol and pharmaceutical industry (Ajaelu, Bamgbose, Atolaiye \& Adetoye, 2008), cassava production has been promoted globally with Food and Agriculture Organisation (FAO) together with International Fund for Agricultural Development (IFAD) being in the forefront promoting its production and utilisation. Together, these organisations developed what they termed as the 'Cassava development strategy and implementation plan' in 2000. The aim was to promote the crop and increase its production and utilisation in Africa, Asia, Latin America and the Caribbean with the vision that cassava would spur rural industrial development and raise incomes for producers, processors and traders and contribute to the food security status of producing and consuming households (FAO \& IFAD, 2001).

In Kenya, the Ministry of Agriculture and Kenya Agricultural Research Institute (KARI), in conjunction with various non-governmental and multilateral organisations have put a lot of effort in promoting cassava as a food crop and an income generating activity with special emphasis on its commercialisation. Rural farm households in the drier areas of Rift Valley, Eastern and Central Provinces have been trained on the agronomical aspects of cassava production, harvesting and postharvest handling techniques and in its utilisation including processing for food and for commercial purposes (Central Kenya Dry Areas Smallholders and Community Services Project [CKDAP], 2011). In addition, farmer groups have been exposed to cassava recipes and technologies suitable for small cottage industry (CKDAP, 2011). Field demonstrations on how to prepare and process cassava have been held in various places. In spite of all the efforts, cassava has not evolved from subsistence to a commercial crop, a factor that undermines its role in fighting food insecurity (New Partnership for Africa's Development [NEPAD], 2010). Its production has remained low in Kenya, concentrated in certain regions especially the western and coastal regions of the country. This has limited its absorption into mainstream value chainsbeing promoted by the government in its bid to develop the agriculture sector and improve its contribution to the national gross domestic product. It therefore became necessary to investigate the level of adoption of cassava commercialisation technologies promoted among rural smallholder households in a bid to understanding challenges to adoption of the technologies. These technologies include improved agronomical practices aimed at increased cassava yields and production, use of agricultural zone-appropriate varieties and value addition through processing into various end products for example chipped and dried cassava, cassava flour, baked and fried products and incorporation of cassava in animal feeds.

Literature abounds with factors influencing adoption of agricultural technologies among smallholder farmers (Abdullah \& Samah, 2013; Mugo, 2012; Muzari et al., 2012; Nsabimana \& Masabo, 2005; Sulo, Koech, Chumo \& Chepng'eno, 2012). Some factors are related to the farmer while others are related to support institutions. Mugo (2012) while researching on factors influencing smallholder farmers' decision to adopt conservative agriculture found a positive and significant influence of age of farmer, education level, farm size, frequency of contact with extension agent and participation in field days while family size, sex of farmer and experience did not affect adoption. Further, Nsabimana and Masabo (2005) found sensitisation on advantages of technology, technical information and exposure to the technology to be important factors influencing adoption of technology. Other factors include assets (both physical and abstract possessions), vulnerability of farmer to economic, biophysical and social risks and institutions that support agriculture (Muzari et al., 2012). Negative farmer perceptions and capacity of extension agents to convince farmers to use technology (Abdullah \& Samah, 2013) have also been mentioned. 
In this paper we endeavour to explore adoption of cassava commercialisation technologies among smallholder farm households that have been exposed to these technologies and the challenges they encounter as they adopt the technologies. The paper is based on the results of a survey conducted to shed light on the proportion of rural smallholder households that have incorporated entrepreneurial activities into cassava production as a means to achieving food security. Some of the specific objectives of the survey, and whose results are presented in this paper were:

- To determine the level of cassava production among rural farm households

- To determine proportion of rural farm households engaging in cassava-related entrepreneurial activities

- To determine the types of cassava-related entrepreneurial activities among rural farm households

- To determine challenges encountered as rural farm households produce and utilise cassava.

\section{Methodology}

\subsection{Area Description}

The study was conducted in Ngata Division of Nakuru District within the Rift Valley province of Kenya. Although Ngata has a potential for agricultural production, $30 \%$ of the population is vulnerable to food hunger (Food security report, 2010). The Ministry of Agriculture and KARI, together with non-governmental organisations have been promoting cassava commercialisation technologies in the Division with the overall goal of enhancing food availability and accessibility.

\subsection{Population of Study and Sample Selection}

Respondents were drawn from groups started by the Ministry of Agriculture, referred to as the cassava common interest groups. Extension services in Kenya are demand-driven, therefore the Ministry of Agriculture works with farmers who show an interest in a particular enterprise, putting them in what is known as 'Common Interest Groups' (CIGs). From the five sub locations that make Ngata Division, 99 smallholder household heads were purposively selected, being all the members that belonged to cassava common interest groups in Ngata Division.

\subsection{Data Collection and Analysis Procedures}

Data was collected through on-farm face-to-face interviews with household heads. The resulting data was analysed descriptively using frequencies, percentages and cross-tabulation analysis with Cramer's $\mathrm{V}$ for testing significance of association between variables. In addition, discussions emanating from a stakeholder workshop held to disseminate the results of the survey were incorporated. The stakeholders involved were farmer representatives, Ministry of Agriculture represented by Deputy District Agricultural Officer, District Agribusiness Officer and Rongai Division extension staff, Ministry of Livestock Development, Agricultural Technology Development Centre (ATDC) Nakuru, Kenya Agricultural Research Institute (Njoro, Embu and Kakamega Centres), Egerton University, animal feed processors, machine fabricators, women and youth groups, non-governmental organisations involved or with interest in the promotion of cassava production and utilisation in Nakuru District, namely Selfhelp Africa (SHA), Farming Systems, and Sustainable Community Development Services (SCODE) Kenya. Thematic analyses of the discussions were carried out. The results are presented in the next section.

\section{Results and Discussions}

\subsection{Socio-Demographic Characteristics of Respondents}

Both female and male respondents were incorporated in the study though female respondents were slightly more than their male counterparts (at $53.3 \%$ and $46.5 \%$ respectively). The implication is that the views of both males and females are incorporated in the study findings. This is crucial because women have been found to contribute $66 \%$ of all the hours worked throughout the world and that men and women do not adopt new technologies at the same rate or benefit equally from their introduction (Sulo, Koech, Chumo, \& Chepng'eno, 2012). It is therefore important to capture views of both women and men in this paper. 
Age of household heads

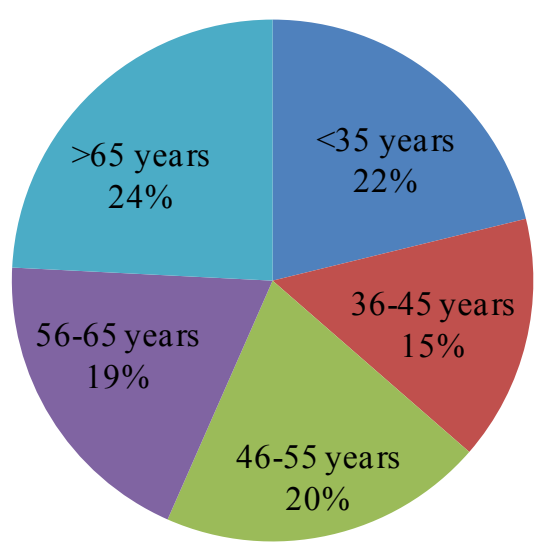

Figure 1. Age of household heads

Figure 1 illustrates that slightly more than half of the respondents (56.6\%) were aged 55 years and below while $24.2 \%$ were above 65 years of age. Age of farmer has been found to influence adoption of technology though, as Akudugu, Guo and Dadzie (2012) report there is contention on the direction of the effect of age on adoption with some researchers finding it positively influencing the rate of adoption and others finding a negative correlation or no significant influence at all.

Table 1. Respondents' level of education

\begin{tabular}{lc}
\hline Respondents' level of education & Percent (\%) \\
\hline No formal education & 10.2 \\
Not completed primary education & 14.3 \\
Completed primary education & 25.5 \\
Not completed secondary education & 6.1 \\
Completed secondary education & 29.6 \\
Tertiary education & 14.3 \\
\hline
\end{tabular}

As shown in Table 1, respondents generally had a high level of education by Kenyan standards with more than $40 \%$ having completed secondary school education. Education has been found to influence adoption of agricultural technology. Education is believed to create a favourable mental attitude for the acceptance of new practices, especially information-intensive and management-intensive practices (Akudugu et al., 2012), with educated farmers preferring to experience the benefits of new technologies (Abdullah \& Samah, 2013). With the high levels of education among the respondents, it is expected that, with other variables held constant, high levels of adoption of cassava commercialisation innovations would be observed.

The main occupation and therefore source of income for most respondents (87\%) was farming. However, $10 \%$ operated businesses besides farming while a further $3 \%$ were in salaried employment alongside farming. Practicing farming on fulltime or part time basis may have an influence on the effort, dedication and value placed on farming with fulltime farmers expected to be more committed to the activity. On the other hand, an extra occupation may mean an extra source of finance that could possibly be invested in farming.

\subsection{Proportion of Households Growing Cassava}

Results indicated that slightly over half the households (57\%) were growing cassava. Both male and female household heads reported growing it at $41.8 \%$ and $58.2 \%$ respectively meaning that more women than men adopted cassava growing. The explanation for this observation could be because cassava is majorly grown for 
food in this region (a concern for women) with only 1.9\% of the respondents (all of whom were men) growing it for business purposes as shown in Figure 2.

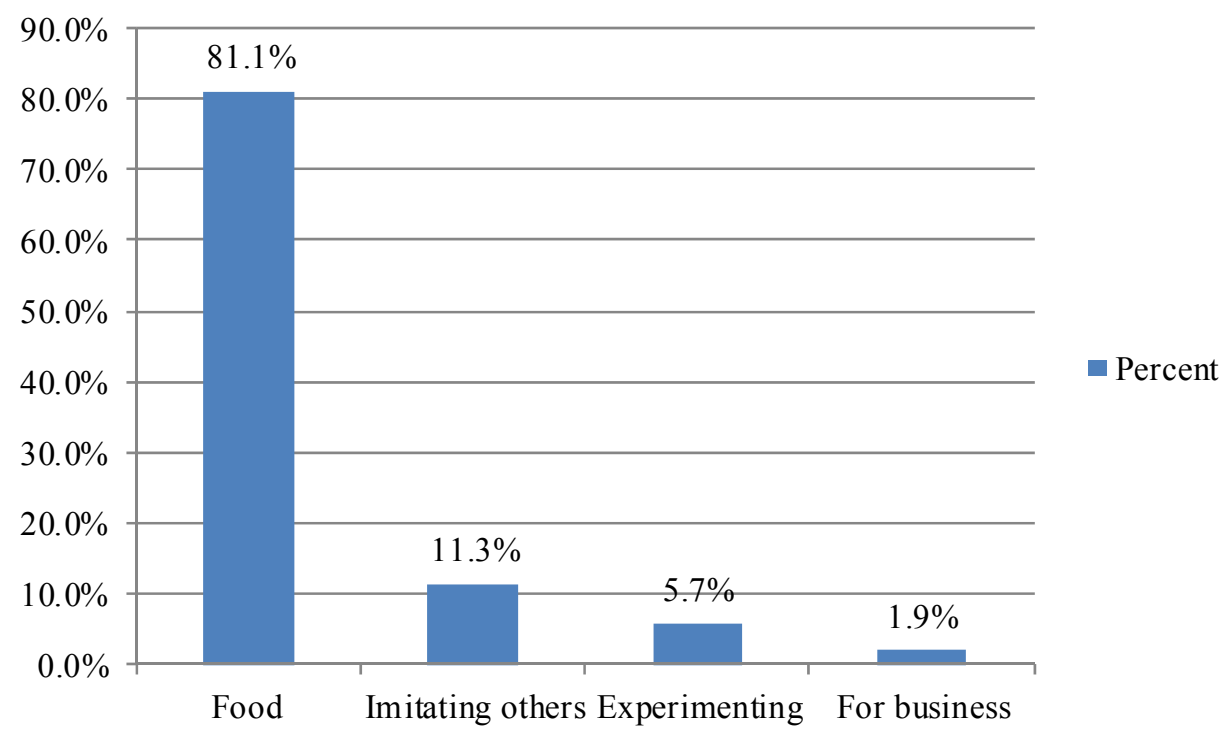

Figure 2. Reasons for growing cassava

Cross-tabulation analysis revealed a significant association between age of farmer and whether or not he or she grew cassava with Cramer's V value of 0.323 at $p=0.037$. A further examination revealed that cassava tended to be grown more by the older farmers compared to the younger farmers as illustrated in Figure 3. A large proportion (69.6\%) of farmers aged above 65 years grew cassava compared to a smaller proportion (33.3\%) of farmers aged below 35 years. This implies that cassava is still a crop for the older generation, a factor that may undermine the sustainability of its adoption.

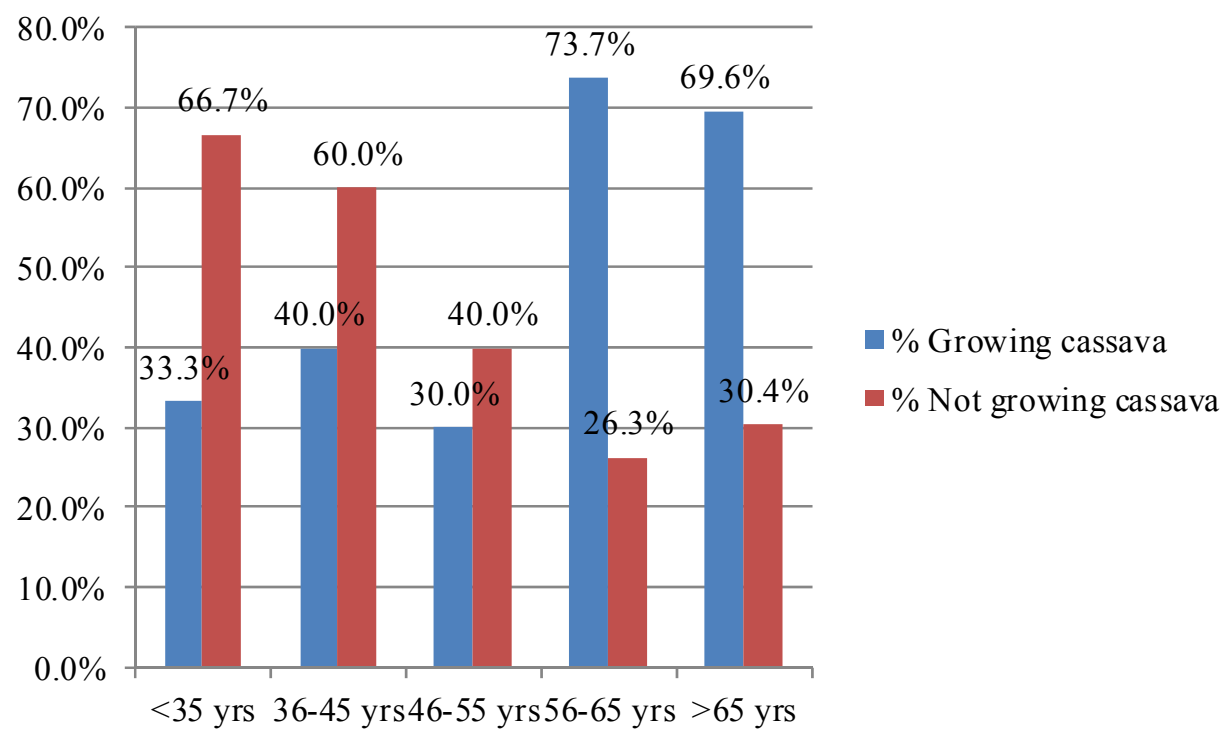

Figure 3. Age of farmer versus cassava growing

When asked to state reasons why they did not grow cassava despite the government's efforts in promoting its production, household heads cited various reasons as indicated in Table 2. Surprisingly, the highly cited reason for not growing cassava was lack of knowledge on how to grow it though over half of the respondents reported 
having been trained on the agronomical aspects of cassava mainly by the Ministry of Agriculture. This may indicate inadequacy in the training offered either in terms of content, form, timing and/or appropriateness.

Table 2. Reasons for not growing cassava

\begin{tabular}{lc}
\hline Reasons & Percent (\%) \\
\hline Lack of knowledge & 54.0 \\
Lack of planting materials & 35.2 \\
Lack of role models & 5.4 \\
Lack of markets & 2.7 \\
Long maturing crop & 2.7 \\
\hline
\end{tabular}

Other reasons cited were lack of planting materials, lack of cassava market and role models and the fact that cassava takes too long to mature. As displayed in Table 3, very few cassava plants were grown per household with majority of the farmers growing less than 20 plants. A few households had utilised more than 0.1 hectares to grow the crop.

Table 3. Amount of cassava grown

\begin{tabular}{ll}
\hline & Percent $(\%)$ \\
\hline$\leq 20$ plants & 51.9 \\
$21-100$ plants & 34.6 \\
0.05 hectare -0.1 hectare & 11.6 \\
$>0.1$ hectare & 1.9 \\
\hline
\end{tabular}

\subsection{Cassava-Related Entrepreneurial Activities within Smallholder Farm Households}

Very few households had adopted cassava growing as an entrepreneurial venture with only $1.9 \%$ growing cassava for business purposes. Households growing cassava for business purposes utilised a bigger portion of land compared to those who grew it solely for food purposes. These were the same households $(1.9 \%)$ that utilised over 0.1 hectares to grow cassava. A further examination revealed that only $6.1 \%$ of the households engaged in cassava-related entrepreneurial activities and all these activities involved selling of raw tubers. There was no cassava processing for entrepreneurial purposes. Some of the cassava processing technologies promoted in Kenya with the hope of igniting entrepreneurial activity include chipping and drying, milling, baking various products and cassava crisps making. 


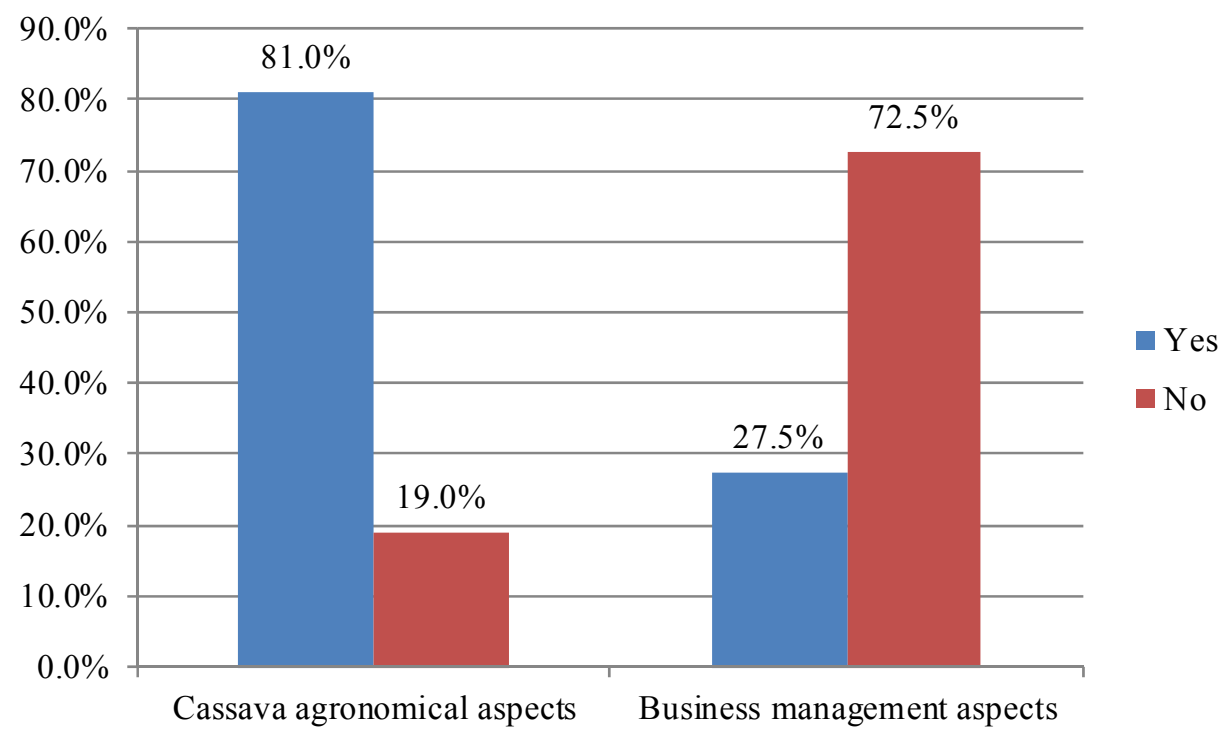

Figure 4. Aspects household heads were trained on

As illustrated in Figure 4, it was ascertained that only $27.5 \%$ of household heads had been trained on business management and related subjects compared to the high number of household heads trained in cassava agronomical aspects (81\%), an indication of the low value placed on smallholder farmer entrepreneurial development. The subjects covered were record keeping, financial management, market identification, advertising and customer care. Business management skills and knowledge are essential in the development of the small and micro enterprise sector through increased efficiency and productivity and in accessing profitable markets (Allal, 1999; Papulova \& Mokros, 2007; United States Agency for International Development, 1998).

In addition, training shapes human motivation factors (Kessy \& Temu, 2010) necessary for engagement in the practice being promoted. None of the interviewed household heads had been trained on entrepreneurial competency development which is necessary for unlocking latent entrepreneurial abilities and empowering those lacking confidence in business practice. Further, experiential training, a crucial method of training in entrepreneurship education (Rae, 2005), was not incorporated in the package offered to household heads. When asked who trained them on business management aspects, the respondents mentioned a variety of institutions with majority of them (58.8\%) citing the Ministry of Agriculture as represented in Table 4.

Table 4. Institutions that trained household heads on business management aspects

\begin{tabular}{ll}
\hline Institution & Percent (\%) \\
\hline Ministry of Agriculture & 58.8 \\
Microfinance institutions & 17.6 \\
Trained in college & 11.8 \\
Egerton University (outreach programme) & 5.9 \\
Farming systems & 5.9 \\
\hline
\end{tabular}

Others were trained by microfinance institutions, in particular Equity Bank, Faulu, Kenya Women Finance Trust and Kenya Rural Enterprise Programme [K-Rep] (17.6\%) as a complement to microfinance programme, probably due to sustainability issues (Henry, 2006). Egerton University students trained a few farmers through outreach programmes and Farming Systems, a Non-Governmental Organisation (NGO) also trained a few. Others were trained in colleges as they pursued their formal education. 


\subsection{Challenges Encountered by Smallholder Farm Households in the Production and Utilisation of Cassava}

Thematic analysis of stakeholder forum discussions revealed a number of challenges impeding smallholder households' production and utilisation of cassava. These challenges are discussed here under three themes: challenges impeding cassava production, those impeding cassava consumption and those impeding cassava commercialisation.

\subsubsection{Challenges to Cassava Production}

Cassava production has not increased much in Kenya as was the vision of those who initiated the cassava promotion activities. It is mainly grown in small quantities alongside the main staples except in western and coastal regions of the country where it is given prominence. A number of challenges that stifle the efforts of cassava promoters were identified. First, availability of cassava planting materials emerged as a major challenge with the main supplier, Kenya Agricultural Research Institute (KARI) unable to satisfy the current demand especially in western and coastal regions of the country. This may call for increased farmer-led bulking sites to multiply the available planting materials. Cleanliness of the available materials is another challenge with cassava Brown Streak Disease and spiralling whitefly being the main threats. Though KARI is developing and disseminating disease-free planting materials, demand outweighs supply. In addition, the country lacks a well-laid down and identifiable cassava seed certification structure making it difficult for farmers to identify clean planting materials.

Second, traditionally cassava occupied an important position as a food security crop for resource-poor farmers due to its resilience especially in face of adverse climatic and soil conditions. Specifically, cassava played a crucial role as substitute for cereals for the poor during the 1984-1985 famine, the worst experienced in Kenya in the $20^{\text {th }}$ Century (Nyamwange, 1995). The fact that cassava was used mainly by the poor has created a negative attitude where it is regarded as a 'poor-man's crop'. This perception is affecting its adoption especially by the young generation and threatens not only its adoption but also its long-term role in fighting food insecurity.

Third, all cassava agronomical practices are labour intensive. The Agricultural Technology Centre under the Ministry of Agriculture has come up with intermediate technology equipment that can be used in planting, weeding and harvesting cassava. Though available, the challenge among smallholder farmers is affordability of these equipment at household level. Structures and systems that enable smallholder farmers to access and utilise these equipments in a sustainable manner that makes economic sense may need to be designed.

\subsubsection{Challenges to Cassava Utilisation}

Cassava utilisation is concentrated in the western and coastal regions of the country, mainly as boiled cassava roots consumed as snacks or with tea (GoK, 2007). A few people dry and mill cassava chips into flour used as blends for cooking ugali (thick porridge which is a common meal in almost all Kenyan households), porridge and for home baking. Leaves are also used as vegetables and livestock fodder. However, the enormous potential of cassava in baking and confectionery industry, starch manufacturing and animal feed industry is yet to be exploited in Kenya (GoK, 2007).

High cyanide levels in cassava have been a major drawback to cassava utilisation as human food in Kenya, where deaths have been reported after consumption of cassava especially during times of famine (Hongo \& Oiye, 2004; Keya, 1996; UNEP/ILO/WHO, 2004). Cyanogenic glucosides in cassava are linamarin $(>90 \%)$ and lostraulin $(<10 \%)$. Cassava varieties have been classified into various groups based on the content of the cyanogenic glucosides (McMahon, White, \& Sayre, 1995). Cyanogenic glucosides concentrations vary as a result of genetic and environmental factors, location, season and soil types (UNEP/ILO/WHO, 2004). Identification of cassava varieties with low cyanogenic glucosides content, and therefore fit for consumption, has proved to be a challenge among households. However, processing technologies that reduce cyanide levels in cassava products exist which households need to be exposed to.

\subsubsection{Challenges to Commercialisation of Cassava}

Smallholder rural households were exposed to cassava value adding technologies with the hope that this would spur entrepreneurial activities thus enhancing cassava commercialisation. However, none of the households was found utilising these technologies. The few farmers that engaged in commercial activities involving cassava sold only raw tubers. Some characteristics of cassava limit its commercial use. One of these characteristics is bulkiness of cassava tubers especially in transportation to far markets and processing places. The inconveniences and expenses accompanying cassava transportation is a discouragement to many smallholder farmers. In addition, cassava tubers are highly perishable and require quick utilisation after harvesting to avoid rotting. Chipping and drying technologies and other processing activities may solve this problem (KARI, 2006). However, 
affordability of the required equipment may be out of reach for most smallholder farmers. Though fabricated within the country, prices of the necessary equipment are high for the average household unless collective action of acquiring them is instituted.

Further, low farmer entrepreneurial orientation was cited as a major challenge in commercialisation of cassava production and utilisation. Entrepreneurial orientation leads to utilisation of market intelligence in exploiting profitable opportunities. It also leads to responsiveness to market demands. Though cassava markets exist especially beyond the borders of Kenya, low entrepreneurial orientation impedes farmers from identifying, accessing and taking advantage of them. Farmers' entrepreneurial capacity will need to be developed if smallholder farming is to be transformed into business opportunities. Processors on the other hand complained of inconsistent availability of cassava for commercial purposes and inconsistent quality. Cassava and cassava products quality standards are inexistent in Kenya mainly because cassava industry has not fully developed. There is not much exportation of cassava and cassava products for commercial purposes and therefore the country does not have an external trade framework.

While other countries have developed extensive uses for cassava such as use of cassava flour in Brazil's confectionery industry, cassava starch produced and used in Thailand and Malaysia for various purposes and cassava animal feeds in Japan, Kenya has a narrow range of cassava products (GoK, 2007). This narrow range of cassava products was cited as a challenge confounded by little product research being witnessed in the country.

\section{Conclusion}

In spite of the Kenyan government's effort to popularise high value traditional crops and encouraging farmers to view farming as business, very few households in Ngata Division have adopted cassava commercialisation technologies. Cassava promotion activities which included demonstration of improved agronomical practices, use of agricultural zone-appropriate cassava varieties and demonstration of value addition technologies and cassava recipes have not been effective in commercialising the crop. These activities focussed more on cassava production and utilisation and not on entrepreneurship development and product research.

Repackaging of promotion messages, perhaps focusing more on cassava industrial use such as starch and animal feed production, may assist in creating an image that appeals to smallholder farmers of all age groups. As results of this study have demonstrated, cassava is grown more by the older farmers as compared to the younger ones. A market-orientated approach that is based on market information and intelligence may need to be adopted in order to enhance cassava visibility (Westby, 2002). Promotion of value chains has been championed as one of the most promising market-orientated approach that would result in the empowerment of smallholder farmers. It is an approach that focuses on equipping farmers with entrepreneurial skills and knowledge to enable them participate as a co-owner of the value chain. Exposure to entrepreneurial skills and knowledge would enable farmers to identify profitable cassava opportunities, mobilise resources and implement appropriate action in order to generate wealth. The results of this study showed that not much entrepreneurial training was carried out among farmers.

Unavailability of adequate disease free planting materials and disease tolerant varieties has impeded the adoption of cassava commercialisation technologies. Concerted effort is required, where research institutions together with other stakeholders including farmers, come up with clean and disease tolerant planting materials as well as developing cassava product prototypes; standardisation organisations developing and implementing cassava quality standards; marketing institutions creating demand for cassava and providing market information to rural households and policy makers developing guidelines for cassava trade.

\section{Acknowledgements}

We would like to thank the National Council for Science and Technology (NCST) for funding this study. In addition, we thank Egerton University, Ministry of Agriculture and Kenya Agricultural Research Institute for logistical support, not forgetting all stakeholders who participated in this study. Finally, we would like to appreciate comments from participants of the $11^{\text {th }}$ International South African Association of Family Ecology and Consumer Science (SAAFECS) where an earlier draft of this paper was presented.

\section{References}

Abdullah, F. A., \& Samah, B. A. (2013). Factors impinging farmers' use of agriculture technology. Asian Social Sciences, 9(3), 120-124. http://dx.doi.org/10.5539/ass.v9n3p120

Ajaelu, J. C., Bamgbose, J. T., Atolaiye, B. O., \& Adefoye, A. A. (2008). The use of methemoglobin complex in estimating cyanogen potential of cassava and cassava products. African Journal of Biotechnology, 7(10), $1585-1587$. 
http://www.academicjournals.org/ajb/PDF/pdf2008/16May/Ajaelu\%20et\%20al.pdf

Akudugu, M. A., Guo, E., \& Dadzie, S. K. (2012). Adoption of modern agricultural production technologies by farm households in Ghana: What factors influence their decision? Journal of Biology, Agriculture and Healthcare, $2(3)$, $1-13$.

Retrieved

from http://www.iiste.org/Journals/index.php/JBAH/article/view/1522/1454

Allal, M. (1999). International best practice in micro and small enterprise development. Working paper no. 2, Micro and small enterprise development and poverty alleviation in Thailand series. Bangkok: International Labor Organization/United Nations Development Programme. Retrieved from www.ilo.org/public/libdoc/ilo/1999/99B09428engl.pdf

Central Kenya Dry Areas Smallholders and Community Services Project (CKDAP). (2011). Taming scarce resources for smallholder livelihoods in the dry areas of Central Kenya. Nairobi, IFAD

Dannson, A., Ezedinma, C., Wambua, T. R., Bashasha, B., Kirsten, J., \& Satorius, K. (2004). Strengthening farm agri-business linkages in Africa: Summary results of five country studies in Ghana, Nigeria, Kenya, Uganda and South Africa. Agricultural Management, Marketing and Finance Service (AGSF) Occasional paper 6, FAO, Rome. Retrieved from ftp://ftp.fao.org/docrep/fao/008/y5785e00.pdf

FAO, \& IFAD. (2001). The global cassava development strategy and implementation plan. Proceedings of the validation forum on the global cassava development strategy 26-28 April 2001. FAO, Rome. Retrieved from www.fao.org/docrep/006e/y0169e00.htm

Food security report. (2010). Food responses to food crisis in Kenya. Kenya Agriculture Research Institute. Retrieved from http://www.foodsecurityportal.org/kenya/food-security-report-prepared-kenya-agricultural-research-institute

GoK. (2004). Strategy for revitalising agriculture 2004-2014. Ministry of Agriculture and Ministry of Livestock and Fisheries Development. Government Printer, Nairobi.

GoK. (2005). Strategic plan of Agriculture 2005-2015. Government Printer, Nairobi.

GoK. (2007). National policy on cassava industry: policy reforms to improve production, research, marketing and regulation in cassava industry (a draft). Government Printer, Nairobi.

Hazell, P., \& Poulton, C. (2007). All-Africa Review of Experiences with Commercial Agriculture: case study on food staples (second draft). World Bank. Retrieved from http://siteresources.worldbank.org/INTAFRICA/257994-1215457/78567/ch10_Food_staples.pdf

Henry, S. (2006). Good practice in business development services: How do we enhance entrepreneurial skills in MFI clients? Toronto: Alterna Savings. Retrieved from www.ruralfinance.org/fileadmin/templates/rflc/documents/Good_Practice_in_Business_Development_Servi ces_pdf

Hongo, T., \& Oiye, S. (2004). News from Kenya: Transferring food technology to the people. Newsline No. 59. Retrieved from Infost.org/publications/newsline/Newsline59.html

Kenya Agricultural Research Institute. (2006). Variety, Characteristics and Production Guidelines of Traditional Food Crops. KARI Katumani Research Centre.

Kenya Agricultural Research Institute. (February, 2011). Retrieved February 17th, 2011, from http://www.kari.org/index.php?q=food=crops-research-programme

Kessy, S., \& Temu, S. S. (2010). The impact of training on performance of micro and small enterprises served by microfinance institutions in Tanzania. Research Journal of Business Management, 4(2), 103-111. Retrieved from http://scialert.net/qredirect.php?doi=rjbm.2010.103.111\&linkid=pdf

Keya, E. L. (1996). Review of Kenyan agricultural research Vol. 10. Food, Feed Science and Human Nutrition. KARI, Nairobi.

McMahon, J., White, W., \& Sayre, R. T. (1995). Cyanogenesis in cassava (Manihot esculenta Crantz). Journal of Experimental Botany, 46, 731-741. http://jxb.oxfordjournals.org/content/46/7/731

Mugo, B. J. (2012). Factors affecting adoption of conservation agriculture among smallholder farmers in Ngata Division, Nakuru County. MA Thesis. University of Nairobi.

Muzari, W., Gatsi, W., \& Muvhunzi, S. (2012). The impacts of technology adoption on smallholder agricultural productivity in Sub-Saharan Africa: A review. Journal of Sustainable Development, 5(8), 69-77. 
http://dx.doi.org/10.5539/jsd.v5n8p69

NEPAD. (2010). Cassava East Africa 2010 Comprehensive Africa Agriculture Development Programme design and implementation workshop value chain working group. NEPAD. Retrieved from http://www.nepad-caadp.net

Nsabimana, J. D., \& Masabo, F. (2005). Factors influencing adoption of agricultural technologies in Kiruhura District of Rwanda. African Crop Science Conference Proceedings, 7, 759-760. Retrieved from http://www.acss.ws/upload/XML/Research/633.pdf

Nyamwange, M. (1995). Famine mitigation in Kenya: Some practices, impact and lessons. Middle States Geographer, 28, 37-44.

Papulova, Z., \& Mokros, M. (2007). Importance of managerial skills and knowledge in management for small entrepreneurs. E-Leader, Prague 2007. Retrieved from www.g-casa.com/PDF/Papulova-Mokros.pdf

Rae, D. (2005). Entrepreneurial learning: a narrative-based conceptual model. Journal of small business and enterprise development, 12(3), 323-335. Retrieved from www.emeraldinsight.com/1462-6004.htm

Sulo, T., Koech, P., Chumo, C., \& Chepng'eno, W. (2012). Socioeconomic factors affecting the adoption of improved agricultural technologies among women in Marakwet County Kenya. Journal of Emerging Trends in Economics and Management Sciences, 3(4), 312-317. Retrieved from $\mathrm{http} / / /$ jetems.scholarlinkresearch.org/articles/Socioeconomic\%20Factors\%20Affecting.pdf

Thapa, T. B. (2000). Small-scale milk processing technologies: Other milk Products. Discussion paper 2.2 (English) In Report; FAO E-mail Conference on Small-scale milk collection and processing in developing countries, 28 May - 29 July 2000 FAO, Rome. Retrieved from http://www.fao.org/ag/againfo/themes/documents/LPS/DAIRY/ecs/Papers/di_pap22.htm

UNEP/ILO/WHO. (2004). Hydrogen cyanide and cyanides: Human health aspects. WHO, Geneva. Retrieved from http://www.inchem.org/documents/cicads/cicads/cicad61.htm

United States Agency for International Development. (1998). Microenterprise Result Reporting. Retrieved 15th May, 2003, from http://www.mrreporting.org/MRR1998/MicroE_MRR_Rpt98_ExSum.htm

Westby, A. (2002). Cassava utilization, storage and small-scale processing. In R. J. Hillocks, J. M. Thresh,\& A. C. Bellotti, Cassava: Biology, production and utilization. CAB International. Retrieved from http:/researchintouse.com/nrk/RIUinfo/outputs/R7497_a.pdf

\section{Copyrights}

Copyright for this article is retained by the author(s), with first publication rights granted to the journal.

This is an open-access article distributed under the terms and conditions of the Creative Commons Attribution license (http://creativecommons.org/licenses/by/3.0/). 